\title{
乳房炎牛の乳頭粘膜における $\operatorname{IgA}$ 陽性細胞の分布
}

\author{
平塚雅之 ${ }^{1 ）}$ 山口高弘 ${ }^{2)}$ 青柳恒夫 ${ }^{1)}$ 鈴木 惇 $^{2)}$ \\ 1）宮城県仙北食肉衛生検查所（产987-03 宮城県登米郡米山町字桜岡今泉 314 ) \\ 2）東北大学農学部（宁981 仙台市青葉区堤通雨宮町 1-1）
}

(1995 年 9 月 6 日受付・1996 年 7 月 10 日受理)

要約

乳房炎乳と判定された乳汁を分泌する乳頭（乳房炎乳頭）における乳管洞乳頭部粘膜固有層の IgA 陽性細胞の分 布を免疫組織化学的に検索した．顕著なリンパ球の浸潤が認められた乳房炎乳頭の粘膜固有層では, IgA 陽性細胞数 の有意の増加が認められた. ——ーワード : 乳頭, $\operatorname{IgA}$ 陽性細胞, 乳房炎, 粘膜免疫.

日獣会誌 49，729～731（1996）

牛の乳房炎は乳頭口から進入した種々の病原微生物の 感染によって誘起される [3]. 感染にともない, 乳頭粘 膜や乳線において好中球やリンパ球などが浸潤・増加し $[10,11]$, 乳汁中の白血球数が増加する $[12]$. また抗原 を感作した分房の乳汁中の免疫グロブリン濃度が上昇す ること $[1,6-8,13] や$, 免疫グロブリン産生細胞数が増加 すること $[9]$ から, 乳腺および乳頭におる局所免疫が誘 導されることが示唆されている. 消化器および呼吸器の 粘膜においては, 分泌型 IgA が病原体の定着阻止に重 要な役割を持つことが知られている 4 ]. 乳管洞乳頭部 粘膜は乳房炎原因菌の最初の感染成立部位と考えられる. Nickerson ら[11] は黄色ブドウ球菌に感染した乳頭に おいて形質細胞やリンパ球が増加することを報告してい る.

本研究では乳房炎乳と判定された乳汁を分泌する乳頭 (乳房炎乳頭) の乳管洞乳頭部粘膜の IgA を分泌する細 胞 (IgA 陽性細胞) を免疫組織化学的に検索し, 乳房 炎にともなう粘膜免疫に関わる IgA 陽性細胞の变化を 検討した.

\section{材料および方法}

と畜場に搬入された 11 頭の乳房炎牛について, 乳管 洞乳頭部粘膜におけるリン八゚球の浸潤程度および孚汁の PL テスターa)による乳房炎検查を実施した。 乳房に近 い乳頭基部, 中間部, 先端部の組織を採取し, ブアン液 で固定後, 常法にしたがってパラフィン包埋し, 薄切片 (2 $\mu \mathrm{m})$ を作製し免疫染色した.

乳房炎乳頭は 12 検体, 正常乳頭は 4 検体, 判定が困 難な乳頭は 2 検体で, 他の 26 検体は乳汁がでない盲乳 乳頭であった (表 1 ).

$\operatorname{Ig} \mathrm{A}$ 陽性細胞は $\mathrm{ABC}$ 法キット $)^{\mathrm{b}}$ を用い, 間接酸素抗 体法で検出した. 一次抗体は抗牛 IgA 鬼血清c), 二次抗
体はビオチン化抗兔 IgG 山羊血清bを使用した。なお， 対照としての切片は一次抗体処理以外は同様に処理した. 乳管洞乳頭部粘膜固有層における $\operatorname{IgA}$ 陽性細胞数は, 各切片当たり 10 視野 $\left(1\right.$ 視野 $\left.=7.5 \times 10^{4} \mu \mathrm{m}^{2}\right)$ について 測定し, 視野当たりの平均細胞数で示した. 試験成績の 有意差検定は $\mathrm{t}$ 検定を用いた.

$$
\text { 成績 }
$$

乳房炎乳頭の 10 検体中 $\mathrm{A}$ 群とされた検体は乳管洞乳 頭部粘膜に著しいリンパ球浸潤（図 1a）を示した. 特 に 5 検体 (1A，2A，3A，6A，6C）では粘膜全域で，2 検体では乳頭の先端部 (11B) と中間部 (4D) の粘膜が 著変を示した. 残りの $\mathrm{B}$ 群 3 検体（3B，3C，8A）では 粘膜のすべての部位に軽度のリン八゙球浸潤が認められた (表 1). 乳房炎陰性で正常乳頭之判定された 4 検体のう ち乳管洞乳頭部粘膜にリンパ球の浸潤が著しい検体 $1 \mathrm{C}$ は外傷性の炎症が疑われ, 正常群として扱わなかった。

免疫組織化学染色により, 乳管洞乳頭部粘膜に分布す る IgA 陽性細胞はび慢性の茶褐色を呈し, 明瞭に識別 された（図 1b). また，粘膜上皮細胞の管腔側表面む陽 性反応を示した. A 群の乳管洞乳頭部の粘膜固有層に おける $\operatorname{IgA}$ 陽性細胞数は正常群（図2）よりあ多かっ た. しかし, $\operatorname{IgA}$ 陽性細胞の分布は必ずしあリンパ球 の浸潤部位と一致しなかった. 対照切片では陽性反応は 認められなかった。

$\mathrm{A}$ 群の乳房炎乳頭の平均 $\operatorname{Ig} \mathrm{A}$ 陽性細胞数は B 群およ び正常群の乳頭のそれより有意に多く（A 群 : 15.8土 2.4 ; B 群 : $6.7 \pm 1.2$; 正常群 : $9.2 \pm 2.4$; A 群一B 群 : $\mathrm{P}$ $<0.01 ; \mathrm{A}$ 群一正常群: $\mathrm{P}<0.05), 7$ 検体中 6 検体で正

a) 日本全薬工業, 福島.

b) Vector Laboratories, U.S.A.

c) Bethyl Laboratories, U.S.A.

日獣会誌 $49 \quad 729 \sim 731 \quad$ (1996) 
表 1 分房の乳質検査成績と乳管洞乳頭部粘膜でのリンパ球 の浸潤度

\begin{tabular}{|c|c|c|c|c|c|c|}
\hline & \multirow{2}{*}{ 乳頭番号1) } & \multicolumn{2}{|c|}{ 乳質検査 } & \multicolumn{3}{|c|}{ リンパ球浸潤度合 ${ }^{4)}$} \\
\hline & & 凝集 & 色調 ${ }^{3)}$ & 先端部 & 中間部 & 基部 \\
\hline \multicolumn{7}{|l|}{ 正常乳頭 } \\
\hline \multirow[t]{4}{*}{ 正常群 } & $1 \mathrm{C}$ & - & \pm & H & $H$ & H \\
\hline & $4 \mathrm{~A}$ & - & - & \pm & \pm & \pm \\
\hline & $11 \mathrm{~A}$ & - & - & + & + & \pm \\
\hline & $11 \mathrm{C}$ & - & - & + & + & + \\
\hline \multicolumn{7}{|c|}{ 乳房炎乳頭 } \\
\hline \multirow[t]{8}{*}{ A 群 } & $1 \mathrm{~A}$ & H & H & H & H & H \\
\hline & $1 \mathrm{D}$ & m & H & ND & ND & ND \\
\hline & $2 \mathrm{~A}$ & m & $H$ & H & H & H \\
\hline & $3 \mathrm{~A}$ & m & - & H & H & H \\
\hline & $4 \mathrm{D}$ & m & H & + & H & \pm \\
\hline & $6 \mathrm{~A}$ & 世 & H & H & H & H \\
\hline & $6 \mathrm{C}$ & m & H & H & $H$ & H \\
\hline & $11 \mathrm{~B}$ & m & $H$ & H & + & \pm \\
\hline
\end{tabular}

乳房炎乳頭

B 群 $\quad 3 \mathrm{~B}$

$3 \mathrm{C}$

$8 \mathrm{~A}$

1) $\mathrm{A}$ ：右前； B：右後； C：左前； D：左後.

2) 一：凝集なし; + ：軽度の明瞭な凝集片; $\mathrm{ml}$ : 粘稠性 の強い多量の凝集片; $\geqq$ \# : 完全な凝塊.

3) - : 黄色; \pm : 薄淡緑色; 十 : 淡緑色; H : 緑色.

4) $\leqq \pm$ : 軽度の浸潤; + ：中等度の浸潤 ; $H$ ：緑色;

ND：観察できず.

常群の乳頭より高値を示した（図 3).A 群における基 部, 中間部, 先端部粘膜での $\operatorname{IgA}$ 陽性細胞数には差は 認められなかった。

\section{考察}

本研究では, 乳房炎に罹患した分房の乳管洞乳頭部粘 膜において，IgA 陽性細胞が増加することを初めて明 らかにした。乳房炎乳頭において，乳管洞乳頭部粘膜の リンパ球の浸潤が著しいものと, 浸潤が軽度なものが観 察され，前者の IgA 陽性細胞の増加は顕著であった。

これは乳房炎分房における炎症反応にともなう局所免疫 反応の程度と広がりの違いによるものと考えられる。リ ンパ球浸潤は局所粘膜での感染に対する組織反応を反映 するむのであり, IgA 陽性細胞の増加は乳頭局所での 炎症反応に付随した免疫応答の一つと理解できる.

Nickerson ら [10]は実験的に黄色ブドウ球菌を感染 させた乳腺組織において, IgA 陽性細胞が増加するこ とを示した. また, 乳房内注入の抗原刺激に対して, 乳

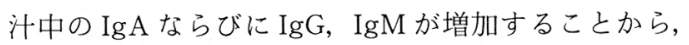
乳腺局所で形質細胞から抗体産生が誘起されることが明 らかにされている $[1,6-8,9,13]$.

今回得られた成績は, 乳腺組織以外に乳頭の粘膜でも 局所免疫応答が起こる可能性を示唆した. Collins ら

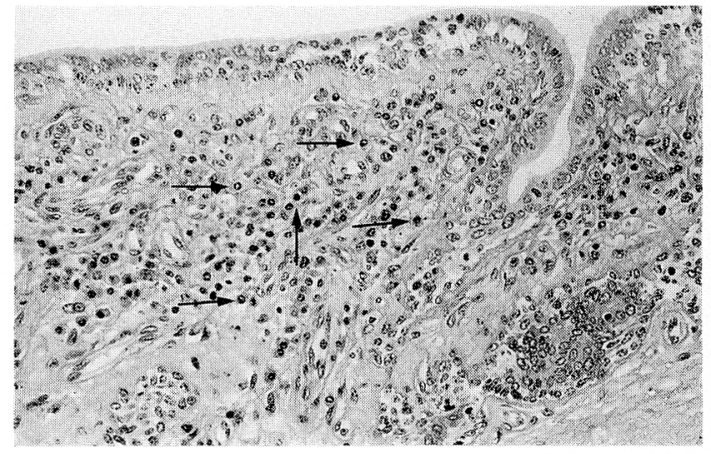

困 1a A 群の乳房炎乳頭の乳管洞乳頭部粘膜固有層にお けるリンパ球の著しい浸潤（HE 染色 $\times 85 ）$.

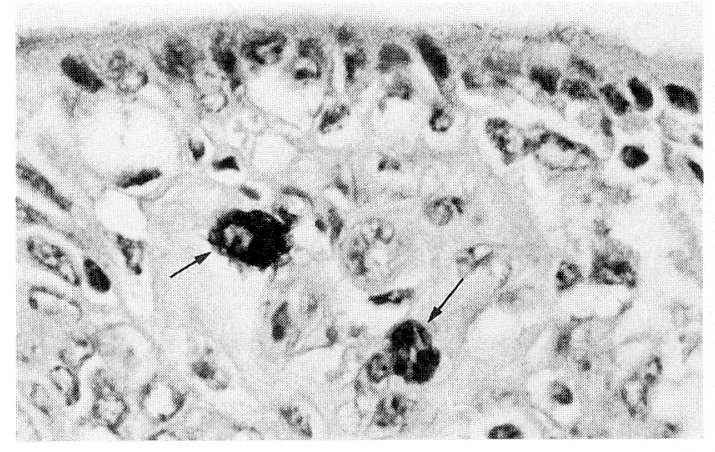

図 $1 \mathrm{~b}$ 乳房炎乳頭の粘膜固有層で観察される IgA 陽性細 胞 (免疫染色 $\times 420)$.

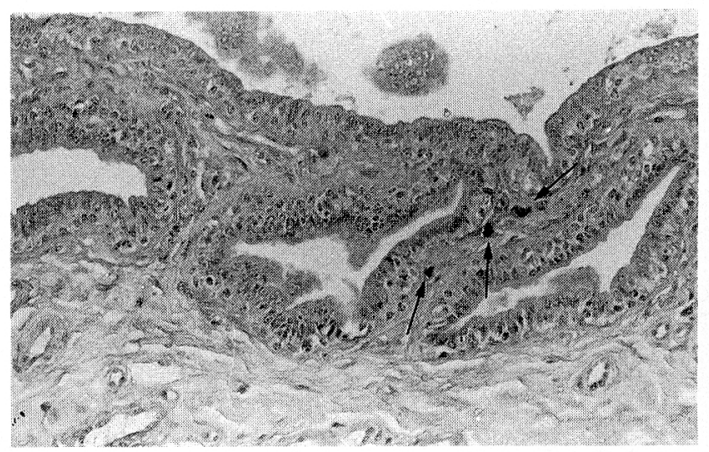

図 2 正常乳頭の粘膜固有層に分布する IgA 陽性細胞は 著しく少ない（免疫染色 $\times 85 ）$.

[2]は乳管洞乳頭部粘膜に $\operatorname{IgG}, \operatorname{IgM}, \operatorname{Ig} A$ 産生細胞が 存在することを証明した。 しかし, 乳房炎の分房乳頭で これらの免疫グロブリン産生細胞がどのように変化する か不明であった，本研究において，乳房炎にとあなうり ンパ球浸潤の顕著な分房では $\operatorname{IgA}$ 陽性細胞の増加とと あに粘膜表面でも IgAの強陽性反応が認められたこと から, 感染分房の乳頭粘膜では乳房炎起因菌に対する 


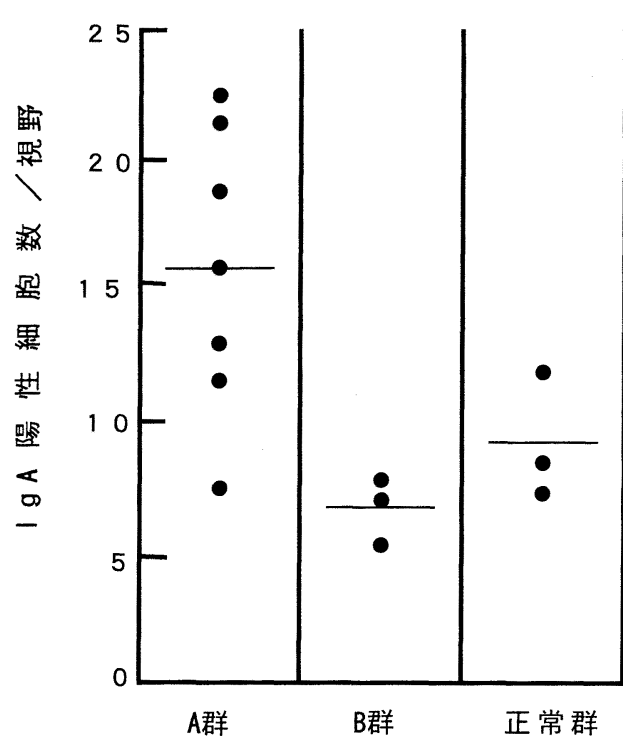

図 3 乳管洞乳頭部粘膜における IgA 陽性細胞数の 比較（A 群, B 群は表 1 を参照)

$\operatorname{Ig} \mathrm{A}$ 抗体が分泌されていると考えられる. 分泌型 $\operatorname{IgA}$ は粘膜において病原微生物の定着因子や運動因子に結合 して感染を阻止することが知られている。したがって, 乳頭局所で産生された IgA 抗体は感染菌の乳頭局所へ の定着や乳管洞乳腺部さらには乳腺への上向阻止に作用 すると考えられる。
以上のことから，本研究の成績は乳頭粘膜における $\operatorname{IgA}$ 陽性細胞および粘膜表面の $\operatorname{IgA}$ の検出が乳頭領域 での感染成立の指標の一つになる可能性を示すと考えら れる.

\section{引用文献}

[1] Boothby JT, Jasper DE, Thomas CB : Can J Vet Res, 51, 121-125 (1987)

[2] Collins RA, Parsons KR, Bland AP : Res Vet Sci, 41, 50-55 (1986)

[3] Jain NC: J Dairy Sci, 62, 128-134 (1979)

[4] 河岡義裕, 内貴正治：獣医領域における免疫学, 伊沢久夫, 他編，219-220，近代出版，東京 (1981)

[5] Lamm ME : Adv Immunol, 22, 225-226 (1976)

[6] Lascelles AK : J Dairy Sci, 62, 154-160 (1979)

[7] Nashar TO, Stokes CR, Cripps PJ : Res Vet Sci, 50, 145-151 (1991)

[8] Newby TJ, Bourne J : J Immunol, 118, 461 - 465 (1977)

[9] Nickerson SC, Baker PA, Trinidad P : J Dairy Sci, 72, 1764-1773 (1989)

[10] Nickerson SC, Heald CW : J Dairy Sci, 65, 105-116 (1982)

[11] Nickerson SC, Pankey JW : Am J Vet Res, 44, 14331441 (1983)

[12] Nickerson SC, Pankey JW : Res Vet Sci, 38, 167-173 (1985)

[13] Yokomizo Y, Norcross NL: Am J Vet Res, 39, 511$516(1978)$

Distribution of IgA-containing Cells in the Mucous Layers of Bovine Teat with Mastitis

Masayuki HIRATSUKA*, Takahiro YAMAGUCHI, Tsuneo AOYAGI and Atsushi SUZUKI

* Miyagi Prefecture Senpoku Meat Sanitation Inspection Laboratory, Yoneyama, Tome, Miyagi, 987-03, Japan

\section{SUMMARY}

The distribution of IgA-containing cells (IgA-cells) was immunohistochemically evaluated in the mucosal layer of the bovine teats lactating milk containing inflammatory exudates. The significantly increased number of IgA-cells was observed in the mucosa with severe infiltration of lymphocytes.

- Key words : bovine teat, IgA-containing cells, mastitis, mucosal immunity.

J. Jpn. Vet. Med. Assoc., 49, 729 731 (1996) 